\title{
Structure and nucleophilic behaviour of secondary and tertiary linear enaminosulfones
}

\author{
Cristina Forzato, Fulvia Felluga, Valentina Gombac, Patrizia Nitti, Giuliana Pitacco, and \\ Ennio Valentin*
}

Dipartimento di Scienze Chimiche, Università degli Studi di Trieste, via Licio Giorgieri 1, I-34127 Trieste, Italy

E-mail:valentin@dsch.univ.trieste.it

\section{Dedicated to Professor Branko Stanovnik on his $65^{\text {th }}$ birthday}

(received 29 Sep 03; accepted 08 Jan 04; published on the web 22 Jan 04)

\begin{abstract}
The structure of enamines derived from 1-phenylsulfonyl-2-propanone was studied and their nucleophilic reactivity towards electrophiles was investigated as far as the equilibrium between the more and less substituted tautomers and the asymmetric induction on the products by a chiral amine moiety are concerned.
\end{abstract}

Keywords: Vinylogous sulfonamides, enamines, nitroolefins, 1,5-asymmetric induction

\section{Introduction}

As known, the enamine system $\mathrm{N}-\mathrm{C}=\mathrm{C}$ is formed by condensation of a ketone (or aldehyde) carbonyl group with a primary or secondary amine (Scheme 1). ${ }^{1}$ Depending on the structure of the parent ketone and the nature of the amine component, various equilibria can be present. For instance, when the parent ketone $\mathbf{1}$ is unsimmetrically substituted, an equilibrium may be established between the two double bond regioisomeric forms 2 and $\mathbf{3}$ (Scheme 1). When the parent amine is primary, an additional equilibrium between the enamine and the imine forms can be present, which is usually shifted towards the imine forms 4 , unless strong electronic factors favouring the conjugated systems $\mathbf{2}$ or $\mathbf{3}$ predominate. ${ }^{2}$

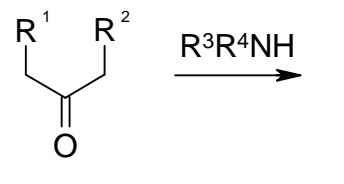

1

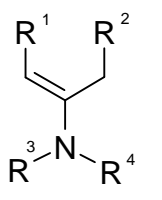

2

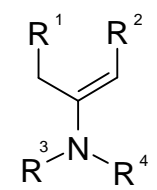

3<smiles>[R]CC(C[R])=N[R]</smiles>

4 
Scheme 1. Possible equilibria in enamines.

The presence of these equilibria can usually be demonstrated spectroscopically or by reaction with an electrophile. In fact, provided the reaction is under kinetic control, either nucleophilic $\beta$ carbon atom is usually more accessible to the approaching electrophile, resulting in the eventual formation of two regioisomeric products, whose relative composition does not reflect the original composition of the parent system. ${ }^{2}$

The presence of a further conjugated additional $\mathrm{C}=\mathrm{C}$ double bond ${ }^{3}$ or of electronwithdrawing groups, such as for instance $\mathrm{C}=\mathrm{O},{ }^{4} \mathrm{C} \equiv \mathrm{N},{ }^{5,6} \mathrm{NO}_{2},{ }^{7} \mathrm{~S}=\mathrm{O},{ }^{8} \mathrm{SO}_{2},{ }^{6,9}$ at either the $\alpha$ or the $\beta$-carbon atom of the enamine carbon-carbon double bond deeply modify the properties of the enamine system.

As expected, the introduction of a sulfone group adjacent to the enamine or imine group has a strong influence on the position of both equilibria. We already studied this influence on tertiary cyclic vinylogous sulfonamides, namely on compounds 5 and $\mathbf{6}$ (Figure 1). ${ }^{10}$ Although they exist as the more substituted tautomers, their reactivity with alkylating and acylating agents as well as with activated olefins and diazenes revealed the existence of a equilibrium between the two double-bond isomers, under the mild reaction conditions employed.

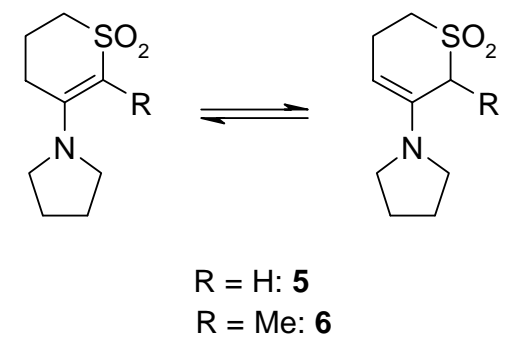

\section{Figure 1}

\section{Results and Discussion}

The present paper deals with the study of the structure and reactivity of enamines derived from a linear $\beta$-ketosulfone, namely 1-phenylsulfonyl-2-propanone 7 (Scheme 2). Ketone 7, which was prepared by a slightly modified version of a literature method, ${ }^{11}$ was reacted with a series of primary and secondary amines 8a-e, namely $n$-butylamine $\mathbf{8 a},(R)$ - $\alpha$-phenylethylamine $\mathbf{8 b}$, morpholine 8c, pyrrolidine $\mathbf{8 d}$ and $(S)$-proline methyl ester $\mathbf{8 e}$. 
<smiles>CC(=O)COS(=O)(=O)c1ccccc1</smiles>

7

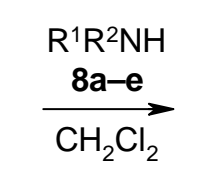<smiles>C=C</smiles>

9a-e<smiles>[R]N([R])C(=C)COS(=O)(=O)O</smiles>

10a-e<smiles>[R]N=C(C)COSc1ccccc1</smiles>

11a,b

\section{Scheme 2}

Linear $\beta$-ketosulfones are not stable under the classical Stork condensation conditions ${ }^{12}$ and under the White and Weingarten conditions. ${ }^{13}$ Therefore, the desired products were prepared by mixing equimolar amounts of the reactants in dichloromethane, in the presence of anhydrous $\mathrm{Na}_{2} \mathrm{SO}_{4}$. Only the preparation of the morpholino derivative 9c required a small amount of $p$ toluenesulfonic acid as a catalyst. The resulting products were pure enough as to be used for the subsequent reactions.

\section{Structures of the substrates}

When the amine component was primary, as for $\mathbf{8 a}$ and $\mathbf{8 b}$, the condensation products were mixtures of enamine and imine forms $\mathbf{9 a / 1 1 a}$ and $\mathbf{9 b} / \mathbf{1 1} \mathbf{b}$ (Scheme 2). Within the imine-enamine equilibrium, the enaminosulfones $9 \mathbf{a}$ and $\mathbf{9 b}$ were the major components, as shown in Table 1, in which the relative ratios are given, together with the $(E) /(Z)$ ratios of the corresponding diastereomers.

Table 1. Relative composition of the substrate mixtures

\begin{tabular}{cccc}
\hline & $(E)-\mathbf{9}$ & $(Z)-\mathbf{9}$ & $\mathbf{1 1}$ \\
\hline a & 38 & 59 & 3 \\
b & 20 & 75 & 5 \\
c & 80 & 20 & \\
d & 100 & - & \\
e & 100 & - & \\
\hline
\end{tabular}

The $(Z)$-isomer prevailed in the mixtures of the secondary enaminosulfones and this can be ascribed to an intramolecular hydrogen bond between an oxygen atom of the sulfone group and the hydrogen atom of the amino group, as suggested by C. J. M. Stirling ${ }^{9}$ for an analogous enaminosulfone 12 (Figure 2), prepared from phenylsulfonylpropyne and benzylamine. As a consequence of this hydrogen bond, the $(Z)$-isomers exhibited the $\mathrm{NH}$ resonance at lower field with respect to the (E)-isomers (7.26 and $7.66 \mathrm{ppm} v s .4 .80$ and $5.53 \mathrm{ppm}$ ).

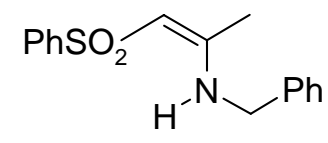




\section{Figure 2}

On the contrary, when the amine component was secondary $(\mathbf{8 c}, \mathbf{d}, \mathbf{e})$, the vinylogous sulfonamides 9c,d,e were proved by NMR to be in $(E)$ configuration either as a major component (9c) or as the sole geometrical isomer (9d and 9e) (Table 1). It must be underline that all the tertiary vinylogous sulfonamides are very rigid as indicated by the extreme broadness of proton and carbon signals.

The geometrical diastereoisomerism of the vinylogous sulfonamide isomers 9a-e was established by DIFNOE measurements (Figure 3), whereas the geometry of the imines $\mathbf{1 1 a}$ and 11b is undetermined as yet.
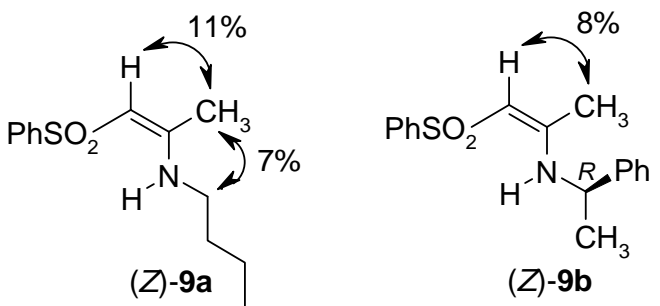

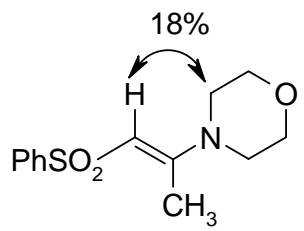

$(E)-9 c$

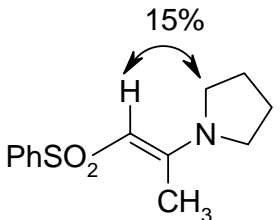

$(E)-9 \mathbf{d}$

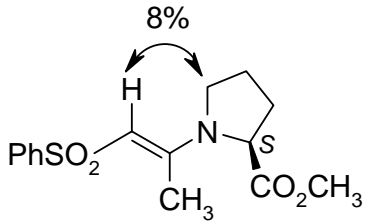

$(E)-9 \mathbf{e}$

Figure 3. DIFNOE measurements for the vinylogous sulfonamides $\mathbf{9 a}-\mathbf{e}$, reporting the resulting $\eta$ values.

\section{Reactions of the enaminosulfones}

The reactivity of these systems towards alkylating and acylating agents, as well as towards some electrophilic olefins were checked. Of all compounds, only 9d was a good substrate in that the products were formed in satisfactory yields. The poor reactivity found for the others can be ascribed either to steric reasons or, in the case of the morpholino derivative, to the lower tendence, with respect to pyrrolidine, of the nitrogen atom for conjugation with the enamine double bond. ${ }^{2}$ However, all reactions were carried out also on the proline derivative $9 \mathbf{e}$, with the aim of verifying a possibile asymmetric induction on the products.

\section{(a) Alkylation reaction}

Enaminosulfones 9d and 9e were reacted with methyl iodide in excess, under heating, to give, after hydrolysis of the crude reaction mixtures, 3-phenylsulfonyl-butane-2-one $\mathbf{1 3},{ }^{14}$ as a result of an attack of the electrophile onto the more substituted $\beta$-carbon atom of the substrates. In the reaction of 9d, the corresponding iminium salt intermediate 14 was isolated and characterized spectroscopically and then hydrolysed. From the reaction of the proline derivative 9e the 
corresponding iminium salt intermediate was not isolated and the ketosulfone $\mathbf{1 3}$ was obtained as a racemate, owing to the acidity of $\mathrm{H}-3$, after purification on column chromatography.

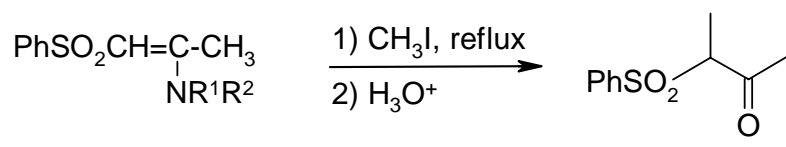

9d, 9e
13

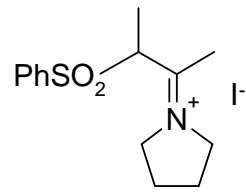

14

Scheme 3. Reactions of vinylogous sulfonamides 9d and 9e with methyl iodide.

\section{(b) Reactions with electrophilic olefins}

Olefins activated by carbonyl groups, such as diethyl maleate, diethyl fumarate, methyl vinyl ketone, proved unreactive, whereas olefins activated by a nitro group were reactive.

In the reaction with 2-nitropropene, the pyrrolidino enamine 9d furnished, after hydrolysis of the crude reaction mixture, the corresponding nitroalkylated ketosulfone as a single regioisomer but as a pair of diastereomers $\mathbf{1 5 , 1 6}$ (Scheme 4). In that case the reactive form was the more substituted tautomer, whereas the proline derivative 9e afforded a 1:9 mixture of the two regioisomers 15,16 and 17 respectively, this latter deriving from the attack of the nitroolefin onto the less substituted enaminosulfone 10e. This result suggests that the presence of the methoxycarbonyl is determinant in directing the electrophile onto the less substituted from of 9e. In both cases the products were racemates.

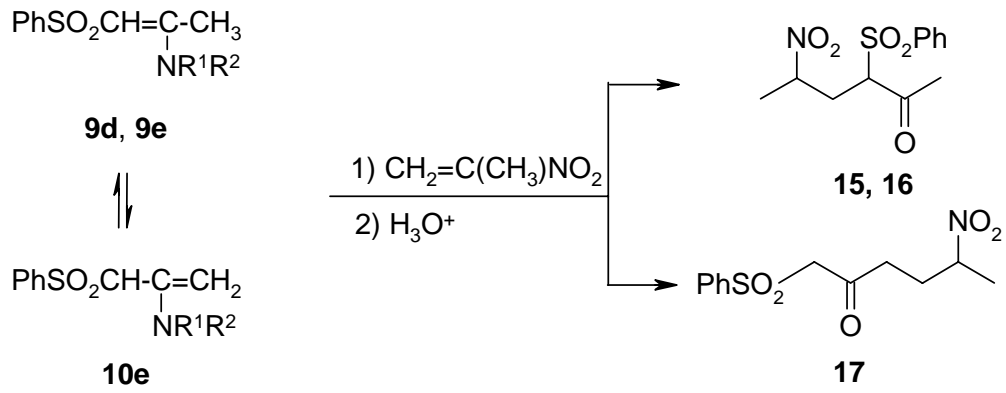

Scheme 4. Reactions of vinylogous sulfonamides 9d and 9e with 2-nitropropene.

The reactions of 9d and 9e with $\beta$-nitrostyrene, carried out in the absence of solvent, in order to improve the yields, allowed the formation of the corresponding enamine intermediates $\mathbf{1 8 d}$ and 18e, each as a single diastereomer, through their respective tautomers $10 d$ and $10 e$. For $18 d$ the double bond configuration was determined to be $(E)$ on the basis of DIFNOE measurements. In fact irradiation of its vinyl proton signal at $4.92 \mathrm{ppm}$ caused enhancement of the signal of the protons adjacent to nitrogen of the pyrrolidine ring $(8 \%)$. The same experiment could not be performed on 18e owing to the broadness of all signals, caused by a severe steric inhibition of 
rotation and therefore the assignment of the $(E)$-configuration to $18 \mathrm{e}$ is based on the observation that in both compounds the respective vinyl proton resonates at $4.92 \mathrm{ppm}$. Remarkable is the fact that 18e is a single isomer, as demonstrated by its ${ }^{13} \mathrm{C}$ NMR spectrum. As the configuration of the proline stereocentre is $S$, that means that the reaction was highly diastereoselective. The enamine 18e exhibited optical activity $\left([\alpha]_{\mathrm{D}}{ }^{25}=-42.2\left(\mathrm{c} 0.30, \mathrm{CHCl}_{3}\right)\right)$, as it did the resulting hydrolysis product $19\left([\alpha]_{\mathrm{D}}{ }^{26}=-12.6\left(\mathrm{c} 0.31, \mathrm{CHCl}_{3}\right)\right)$. It is interesting to note that the same reaction carried out on enamine $9 \mathbf{b}$, which possesses the $R$ configuration, afforded as the final product 19 having the opposite sign of rotation $\left([\alpha]_{\mathrm{D}}{ }^{26}=+6.1\left(\mathrm{c} 0.18, \mathrm{CHCl}_{3}\right)\right)$ as that isolated from $9 \mathrm{e}$.

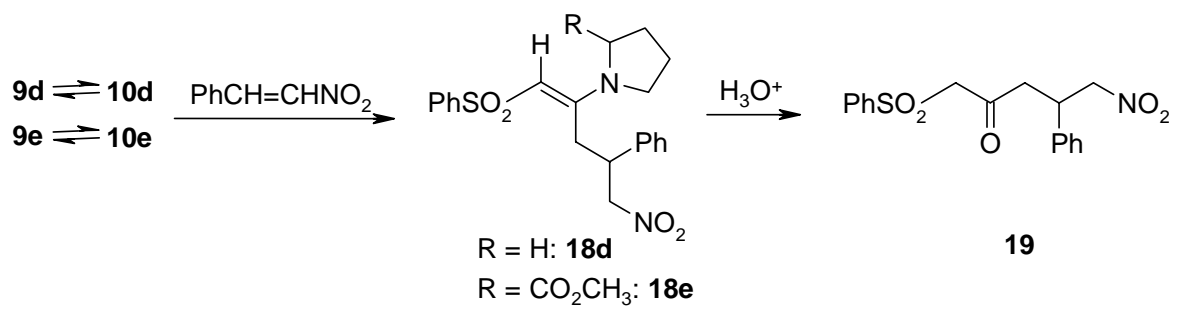

Scheme 5. Reactions of vinylogous sulfonamides $9 \mathrm{~d} \leftrightarrows$ 10d and $9 \mathrm{e} \leftrightarrows$ 10e with $\beta$-nitrostyrene.

The reactions of the two substrates 9d and 9e with (E)-2-nitro-1-phenylpropene followed the same trend already found for $\beta$-nitrostyrene. A pair of diastereomeric nitroalkylated enamines in (E) configuration were formed in each case, $20 \mathbf{d}, 21 \mathrm{~d}$ and $20 \mathbf{e}, 21 \mathrm{e}$ (Scheme 6).

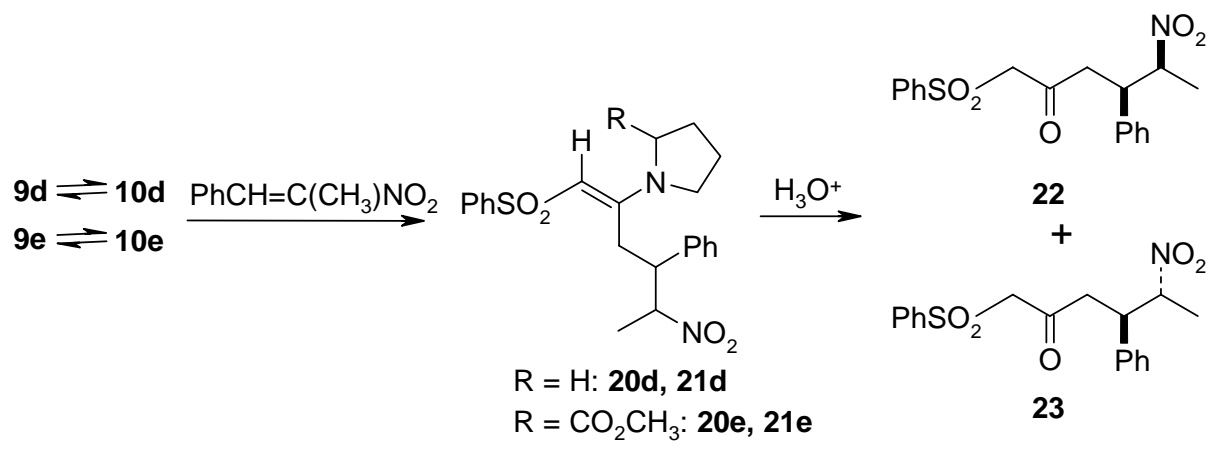

Scheme 6. Reactions of vinylogous sulfonamides 9d $\leftrightarrows$ 10d and 9e $\leftrightarrows$ 10e with (E)-2-nitro-1phenylpropene.

Source of the diastereomerism was the nitromethine carbon atom. This was demonstrated by DIFNOE measurements and by the fact that upon hydrolysis, both pairs of nitroalkylated enamines afforded the same nitroalkylated ketosulfone, as a pair of syn:anti diastereomers 22,23 in the ratio of about 1:1. These latter compounds were separated by flash chromatography and 
they were proved to interconvert easily in chloroform on acidic treatment. From these results it seems reasonable to conclude that also with this nitroolefin the reaction was stereoselective.

The diastereomers $\mathbf{2 2}$ and $\mathbf{2 3}$ were assigned the syn and anti configuration respectively, on the basis of a comparison between the values of their respective ${ }^{3} \mathrm{~J}$ between the benzylic and nitromethinic protons. In compound 22 its value is $6.8 \mathrm{~Hz}$, while in compound 23 it is $9.8 \mathrm{~Hz} .{ }^{15}$ This attribution was confirmed by a comparison of their respective ${ }^{13} \mathrm{C}$ NMR spectra. The signals of the carbon atoms of the syn diastereomer 22 were upfield with respect to the same carbon atoms in $\mathbf{2 3}$, as a result of a bulkier steric situation. Both compounds, when derived from 9e $\leftrightarrows$ 10e, exhibited optical activity (Experimental).

$\alpha$-Nitrostilbene reacted with the vinylogous sulfonamides $9 \mathrm{~d} \leftrightarrows \mathbf{1 0 d}$ and $9 \mathrm{e} \leftrightarrows \mathbf{1 0 e}$ in the same manner as the other nitroolefins bearing the phenyl group at the electrophilic carbon atom. Unfortunately the corresponding nitroalkylated enamines could not be isolated. After hydrolysis of the crude reaction mixtures, a 80:20 mixture of $\mathbf{2 4}$ and its diastereomer $\mathbf{2 5}$ was isolated, from which the main product $\mathbf{2 4}$ was obtained as a pure isomer by flash chromatography. When derived from 9e, it exhibited optical activity (Experimental). Mild acidic treatment of 24 afforded the thermodynamically controlled mixture of $\mathbf{2 4}$ and $\mathbf{2 5}$ in the ratio of 80:20, thus demonstrating that they differed in the configuration of the nitromethine carbon atom.

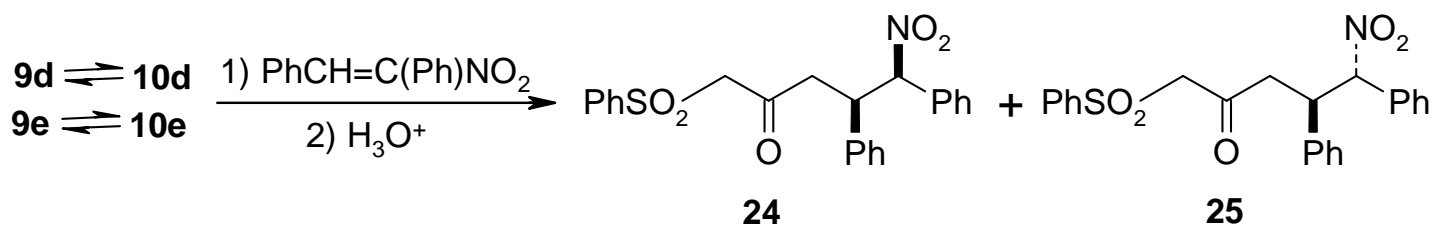

Scheme 7. Reactions of vinylogous sulfonamides 9d $\leftrightarrows 10 d$ and $9 \mathrm{e} \leftrightarrows 10 \mathrm{e}$ with $\alpha$-nitrostilbene.

All the nitroolefins bearing a phenyl group at the electrophilic carbon atom behaved in the same manner with the enamine substrate containing the proline moiety. The tautomeric form 10e was approached by the reagents from the less sterically demanding side of the molecule, namely from that containing the hydrogen atom of the stereocentre (Scheme 8). Although the enamine nucleophilic $\beta$-carbon atom is not prochiral, the approach of the nitroolefin is likely to undergo a 1,5-asymmetric induction, following the topological rule by Seebach and Prelog, ${ }^{16}$ thus generating the zwitterionic intermediate 26. Subsequently the nitroalkylated enamines $\mathbf{1 8 e}$ and 20e, 21e were formed by a stereoselective abstraction of either acidic hydrogen atom adjacent to the sulfonyl group by the carbanion. In fact the geometry of the enamines is $E$ and this requires abstraction of the hydrogen atom indicated in Scheme 8. 


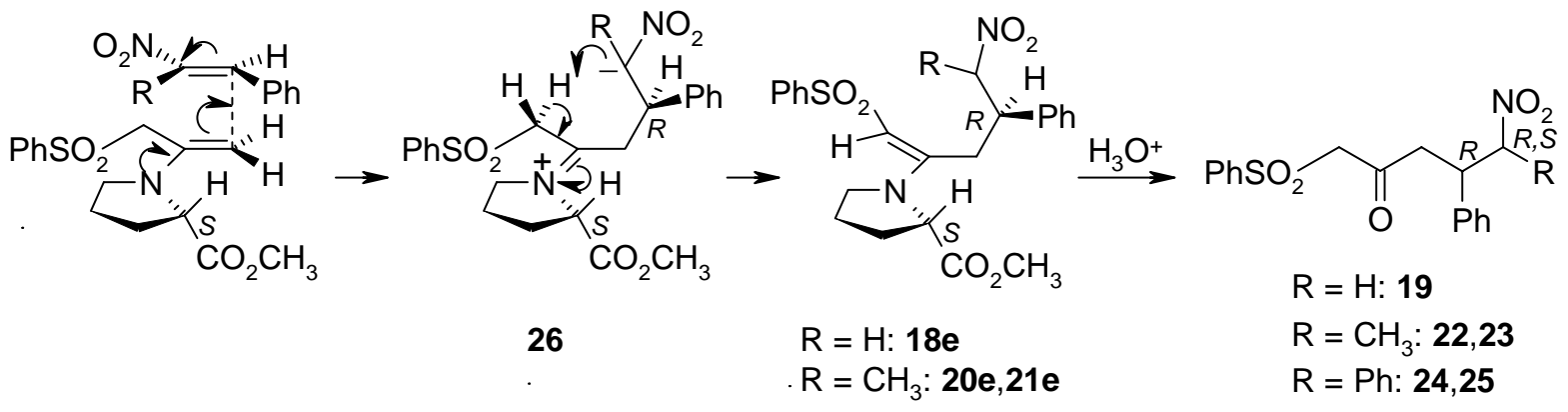

Scheme 8. Preferred topological approach of the nitroolefins onto the less substituted enamine 10 e.

As a consequence of the stereoselective topological approach of the nitroolefin onto the less substituted $\beta$-carbon, it is reasonable to assume that the newly created stereocentre possesses the $R$ configuration.

An analogous mechanism also holds for the pyrrolidine substrate 9d $\leftrightarrows$ 10d, for which however no diastereopreference in the approach of the reactants is possible.

\section{Conclusions}

It is evident that the reactivity of these vinylogous sulfonamides is largely dominated by steric effects. In fact when the electrophilic carbon atom of the reactant is unsubstituted, as it is the case of methyl iodide and 2-nitropropene, the reactive form is the more substituted enamine tautomer 9, whereas in the other cases in which the electrophilic carbon atom bears a phenyl group, it is the less substituted form $\mathbf{1 0}$ of the enaminosulfone system which undergoes attack by the electrophile. With the enamine derived from proline, 9e $\leftrightarrows \mathbf{1 0 e}$, the approach of the reactant is highly stereoselective, leading to optically active products, whose absolute configuration was not established as yet, although the mechanism proposed seems quite plausible.

\section{Experimental Section}

General Procedures. Melting points were determined with a Büchi 510 apparatus and are uncorrected. Column chromatography was performed on silica gel (Merck 60, 70-230 mesh). The $R_{\mathrm{f}}$ values were measured on silica gel pre-coated TLC plastic sheets of silica gel $60 \mathrm{~F}_{254}$ (Merck) with the indicated eluent. NMR spectra were recorded on a Jeol 400 (9.4 Tesla, 400.13 $\mathrm{MHz}$ for ${ }^{1} \mathrm{H}, 100.62 \mathrm{MHz}$ for ${ }^{13} \mathrm{C}$ ) spectrometer. Chemical shifts ( $\delta$ in ppm) are given from internal $\mathrm{CHCl}_{3}$ (7.26) for ${ }^{1} \mathrm{H}$ NMR and ${ }^{13} \mathrm{CDCl}_{3}$ (77.0) for ${ }^{13} \mathrm{C}$ NMR. Coupling constants $(J$ in 
$\mathrm{Hz}$ ) are accurate to $\pm 0.2 \mathrm{~Hz}$ for ${ }^{1} \mathrm{H}$. IR spectra were recorded for nujol or neat on a Jasco FT-IR 200 spectrometer; the absorption values are given in $\mathrm{cm}^{-1}$. Optical rotations were measured with a Perkin-Elmer Model 241 instrument. The designation $c$ refers to concentration in $\mathrm{g} / 100 \mathrm{~mL}$. $\beta$-Nitrostyrene was purchased from Sigma-Aldrich, while the other nitroolefins were prepared in accordance with literature procedures, as follows: 2-nitropropene in accordance with ref. 17, (E)2-nitro-1-phenylpropene according to ref. 18 and $(E)$ - $\alpha$-nitrostilbene according to ref. 19.

1-Phenylsulfonyl-2-propanone (7). Ketosulfone 7 was prepared by a slightly modified version of the literature method. ${ }^{11}$ To a solution of $\mathrm{PhSO}_{2} \mathrm{Na}(4.2 \mathrm{~g}, 25 \mathrm{mmol})$ in DMF, chloroacetone $(2.6 \mathrm{~g}, 25 \mathrm{mmol})$ was added. The reaction mixture was stirred at room temperature for $7 \mathrm{~h}$, poured into iced water $(20 \mathrm{~mL})$ and the product was filtered off and dried in the air $(4.06 \mathrm{~g}$, $82 \%)$. M. p. $57{ }^{\circ} \mathrm{C}$. IR data: $1720(\mathrm{C}=\mathrm{O}), 1320,1310,1300,1150\left(\mathrm{SO}_{2}\right), 750,720,690(\mathrm{Ph})$. NMR data: $\delta_{\mathrm{H}}\left(\mathrm{CDCl}_{3}\right) 7.90(2 \mathrm{H}, \mathrm{d}, \mathrm{Ar}-\mathrm{H}), 7.68(1 \mathrm{H}, \mathrm{t}, \mathrm{Ar}-\mathrm{H}), 7.58(2 \mathrm{H}, \mathrm{t}, \mathrm{Ar}-\mathrm{H}), 4.15(2 \mathrm{H}, \mathrm{s}$, $\left.\mathrm{CH}_{2}\right), 2.40\left(3 \mathrm{H}, \mathrm{s}, \mathrm{CH}_{3}\right) . \delta_{\mathrm{C}}\left(\mathrm{CDCl}_{3}\right) 195.8(\mathrm{~s}), 138.6(\mathrm{~s}), 134.2(\mathrm{~d}), 129.3(2 \mathrm{~d}), 128.1(2 \mathrm{~d}), 67.5$ (t), 31.4 (q).

\section{Preparation of enaminosulfones}

To a magnetically stirred solution of the ketosulfone 7 (2.5 mequiv) in $\mathrm{CH}_{2} \mathrm{Cl}_{2}(5 \mathrm{~mL} / \mathrm{meq})$ the appropriate amine $(2.5 \mathrm{meq})$ and anhydrous $\mathrm{Na}_{2} \mathrm{SO}_{4}$ were added. The mixture was kept at room temperature until consumption of the parent ketone 7. After elimination of $\mathrm{CH}_{2} \mathrm{Cl}_{2}$, the oily residue was solidified on cooling. In any case, the resulting enaminosulfone was pure enough to be used as such.

$(E)$ and (Z)-2-( $N$-Butylamino)-1-phenylsulfonylpropene (9a) and $N$-butyl-1-phenylsulfonyl2-propanimine (11a). Mp $99-100^{\circ} \mathrm{C}(90 \%$ yield). The product is a mixture of $(E)-9 a,(Z)-9 a$ and 11a in the ratio 38: 59:3. IR data $\left(\mathrm{cm}^{-1}\right): 3330(\mathrm{NH}), 3080,3070(=\mathrm{C}-\mathrm{H}), 1575(\mathrm{C}=\mathrm{N}), 1530$ $(\mathrm{C}=\mathrm{C}$ and $\mathrm{NH}), 1310,1280,1120,1070\left(\mathrm{SO}_{2}\right), 805(=\mathrm{C}-\mathrm{H}), 760,710,690(\mathrm{Ph})$. For sake of clarity the spectral values are given separately for the three tautomers.

(E)-9a. NMR data: $\delta_{\mathrm{H}}\left(\mathrm{CDCl}_{3}\right) 7.86(2 \mathrm{H}, \mathrm{m}, \mathrm{Ar}-\mathrm{H}), 7.48(3 \mathrm{H}, \mathrm{m}, \mathrm{Ar}-\mathrm{H}), 5.00(1 \mathrm{H}, \mathrm{s}, \mathrm{C}=\mathrm{CH})$, $4.33(1 \mathrm{H}, \mathrm{bs}, \mathrm{NH}), 2.73\left(2 \mathrm{H}, \mathrm{dt}, \mathrm{J}=6.4,7.0 \mathrm{~Hz}, \mathrm{CH}_{2} \mathrm{NH}\right), 2.12\left(3 \mathrm{H}, \mathrm{s}, \mathrm{CH}_{3}\right), 1.55(2 \mathrm{H}, \mathrm{m}$, $\left.\mathrm{NCH}_{2} \mathrm{CH}_{2}\right), 1.34\left(2 \mathrm{H}, \mathrm{m}, \mathrm{NCH}_{2} \mathrm{CH}_{2} \mathrm{CH}_{2}\right), 0.91\left(3 \mathrm{H}, \mathrm{t}, \mathrm{J}=7.3 \mathrm{~Hz}, \mathrm{CH}_{2} \mathrm{CH}_{3}\right) . \delta_{\mathrm{C}}(\mathrm{CDCl} 3) 156.3$ (s), $145.8(\mathrm{~s}), 131.4(\mathrm{~d}), 128.70(2 \mathrm{~d}), 126.1(2 \mathrm{~d}), 91.7(\mathrm{~d}), 43.2(\mathrm{t}), 30.2(\mathrm{t}), 20.1(\mathrm{t}), 20.0(\mathrm{q})$, $13.6(\mathrm{q})$.

(Z)-9a. NMR data: $\delta_{\mathrm{H}}\left(\mathrm{CDCl}_{3}\right) 7.86(2 \mathrm{H}, \mathrm{m}, \mathrm{Ar}-\mathrm{H}), 7.48(3 \mathrm{H}, \mathrm{m}, \mathrm{Ar}-\mathrm{H}), 7.27(1 \mathrm{H}, \mathrm{bs}, \mathrm{NH})$, $4.54(1 \mathrm{H}, \mathrm{s}, \mathrm{C}=\mathrm{CH}), 3.15\left(2 \mathrm{H}, \mathrm{dt}, \mathrm{J}=6.6,7.0 \mathrm{~Hz}, \mathrm{CH}_{2} \mathrm{NH}\right), 1.88\left(3 \mathrm{H}, \mathrm{s}, \mathrm{CH}_{3}\right), 1.55(2 \mathrm{H}, \mathrm{m}$, $\left.\mathrm{NCH}_{2} \mathrm{CH}_{2}\right), 1.36\left(2 \mathrm{H}, \mathrm{m}, \mathrm{NCH}_{2} \mathrm{CH}_{2} \mathrm{CH}_{2}\right), 0.93\left(3 \mathrm{H}, \mathrm{t}, \mathrm{J}=7.3, \mathrm{CH}_{2} \mathrm{CH}_{3}\right) . \delta_{\mathrm{C}}\left(\mathrm{CDCl}_{3}\right) 157.1(\mathrm{~s})$, $145.2(\mathrm{~s}), 131.8$ (d), 128.9 (2d), 126.1 (2d), 87.8 (d), 42.9 (t), $32.3(\mathrm{t}), 20.1(\mathrm{q}), 19.9(\mathrm{t}), 13.7$ (q). 11a. Owing to superpositions, the data are not complete. NMR data: $\delta_{\mathrm{H}}\left(\mathrm{CDCl}_{3}\right) 4.03(\mathrm{~s}$, $\left.\mathrm{CH}_{2} \mathrm{SO}_{2}\right), 2.78\left(\mathrm{~m}, \mathrm{CH}_{2} \mathrm{~N}\right), 2.03\left(\mathrm{~s}, \mathrm{CH}_{3}\right), 1.11\left(\mathrm{~m}, \mathrm{CH}_{2}\right), 0.82\left(\mathrm{t}, \mathrm{CH}_{2} \mathrm{CH}_{3}\right) . \delta_{\mathrm{C}}\left(\mathrm{CDCl}_{3}\right) 165.0$ (s), $133.8(\mathrm{~d}), 129.1(\mathrm{~d}), 128.3(\mathrm{~d}), 68.0(\mathrm{t}), 51.9(\mathrm{t}), 32.3(\mathrm{t}), 18.4(\mathrm{q}), 13.9$ (q). Anal. Calcd for $\mathrm{C}_{13} \mathrm{H}_{19} \mathrm{NO}_{2} \mathrm{~S}: \mathrm{C} 61.63, \mathrm{H}$ 7.56, N 5.53. Found: C 61.50, H 7.51, N 5.90. 


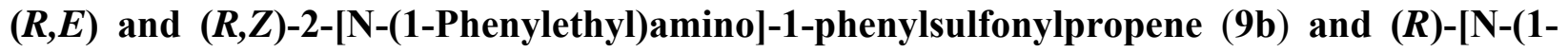
phenylethyl)amino]-1-phenylsulfonyl-2-propanimine (11b). $\mathrm{Mp} 82-4^{\circ} \mathrm{C}(92 \%$ yield). The product is a mixture of three isomers, $(E)-9 b,(Z)-9 b$ and $\mathbf{1 1 b}$ in the ratio 20:75:5. IR data $\left(\mathrm{cm}^{-1}\right)$ : 3310, $1510(\mathrm{NH})$ 1580, $1570(\mathrm{C}=\mathrm{N}), 1280,1250,1100,1060\left(\mathrm{SO}_{2}\right), 800(=\mathrm{C}-\mathrm{H})$. NMR data: $\delta_{\mathrm{H}}$ $\left(\mathrm{CDCl}_{3}\right) 7.88$ (1 H, m, Ar-H), 7.67 (1 H, bd, J 7.8, NH), 7.59 (0.6 H, m, Ar-H), 7.53 - 7.44 (1.6 H, m, Ar-H), 7.40 (0.6 H, m, Ar-H), 7.34 - 7.15 (6.2 H, m, Ar-H), 5.53 (1 H, d, J = 5.9 Hz, NH); the remaining proton signals are listed in Table 2, together with the main carbon signals. The carbon doublets relative to the aromatic rings were too crowded to be assigned correctly. Anal. Calcd for $\mathrm{C}_{17} \mathrm{H}_{19} \mathrm{NO}_{2} \mathrm{~S}$ : C 67.74, $\mathrm{H} 6.35, \mathrm{~N} 4.65$. Found: $\mathrm{C} 67.50, \mathrm{H} 6.53, \mathrm{~N} \mathrm{4.88}$. $[\alpha]_{\mathrm{D}}{ }^{26}=-$ $210.2\left(\mathrm{c}=0.52, \mathrm{CHCl}_{3}\right)$.

Table 2. Partial ${ }^{1} \mathrm{H}$ and ${ }^{13} \mathrm{C}$ NMR data for vinylogous sulfonamides $\mathbf{9 b}$ and imine $\mathbf{1 1 b}$

\begin{tabular}{|c|c|c|c|c|c|c|}
\hline & $\begin{array}{c}(Z)-9 b \\
75 \%\end{array}$ & & $\begin{array}{c}(E)-9 \mathbf{b} \\
20 \%\end{array}$ & & $\begin{array}{c}11 b, \\
5 \%\end{array}$ & \\
\hline $\mathbf{C H}_{3} \mathrm{CH}$ & $1.47(\mathrm{~d})$ & $24.6(q)$ & $1.39(\mathrm{~d})$ & $23.4(q)$ & $1.18(\mathrm{~d})$ & $23.7(q)$ \\
\hline $\mathrm{CH}_{3} \mathrm{C}=\mathrm{N}$ & & & & & $2.16(\mathrm{~s})$ & $18.3(q)$ \\
\hline $\mathrm{CH}_{3} \mathrm{C}=\mathrm{C}$ & $1.70(\mathrm{~s})$ & $20.1(q)$ & $2.09(\mathrm{~s})$ & $18.3(q)$ & & \\
\hline $\mathrm{CH}_{3} \mathbf{C H}$ & 4.55 (quint) & $52.8(\mathrm{~d})$ & 4.30 (quint) & $53.1(\mathrm{~d})$ & $4.50(q)$ & $59.9(d)$ \\
\hline $\mathrm{CH}_{2} \mathrm{SO}_{2}$ & & & & & $4.08(\mathrm{~s})$ & $68.0(\mathrm{t})$ \\
\hline $\mathrm{N}-\mathrm{C}=\mathbf{C H}$ & $4.60(\mathrm{~s})$ & 89.1 (d) & $4.83(\mathrm{~s})$ & $93.2(\mathrm{~d})$ & & \\
\hline $\mathrm{N}-\mathbf{C}=\mathrm{CH}$ & & $156.6(\mathrm{~s})$ & $155.7(\mathrm{~s})$ & & & \\
\hline $\mathrm{C}-1 \mathrm{PhSO}_{2}$ & & $145.5(\mathrm{~s})$ & $145.7(\mathrm{~s})$ & & & $144.1(\mathrm{~s})$ \\
\hline $\mathrm{C}-1 \mathrm{Ph}$ & & $144.0(\mathrm{~s})$ & $142.3(\mathrm{~s})$ & & & not det. \\
\hline
\end{tabular}

(E)- and (Z)-2-(4-Morpholinyl)-1-phenylsulfonyl-propene (9c). Formation of the product from ketone 7 and morpholine was induced by a small amount of $p$-toluenesulfonic acid. The resulting compound 9c, was obtained as a thick oil (90\% yield). The product 9c was a 4:1 mixture of $(E)$ 9c and (Z)-9c. IR data: $3025(=\mathrm{C}-\mathrm{H}), 1560(\mathrm{C}=\mathrm{C}), 1385,1380,760,695(\mathrm{Ph}), 1310,1280,1130$, $1120\left(\mathrm{SO}_{2}\right), 820(=\mathrm{C}-\mathrm{H})$.

For sake of clarity the NMR values are given separately.

(E)-9c. NMR data: $\delta_{\mathrm{H}}\left(\mathrm{CDCl}_{3}\right) 7.85(2 \mathrm{H}, \mathrm{d}, \mathrm{Ar}-\mathrm{H}), 7.45(3 \mathrm{H}, \mathrm{m}, \mathrm{Ar}-\mathrm{H}), 5.21(1 \mathrm{H}, \mathrm{s}, \mathrm{C}=\mathrm{CH})$, $3.65\left(4 \mathrm{H}, \mathrm{t}, \mathrm{CH}_{2} \mathrm{OCH}_{2}\right), 3.14\left(4 \mathrm{H}, \mathrm{t}, \mathrm{CH}_{2} \mathrm{NCH}_{2}\right), 2.14\left(3 \mathrm{H}, \mathrm{s}, \mathrm{CH}_{3}\right) . \delta_{\mathrm{C}}\left(\mathrm{CDCl}_{3}\right) 157.9$ (s) 144.9 (s), $131.4(\mathrm{~d}), 128.5(2 \mathrm{~d}), 125.7(2 \mathrm{~d}), 97.0$ (d), 65.5 (2t), $45.8(2 \mathrm{t}), 14.8(\mathrm{q})$.

(Z)-9c. NMR data: $\delta_{\mathrm{H}}\left(\mathrm{CDCl}_{3}\right) 7.71(2 \mathrm{H}, \mathrm{d}, \mathrm{Ar}-\mathrm{H}), 7.62(1 \mathrm{H}, \mathrm{t}, \mathrm{Ar}-\mathrm{H}), 7.17(2 \mathrm{H}, \mathrm{d}, \mathrm{Ar}-\mathrm{H}), 4.86$ $(1 \mathrm{H}, \mathrm{s}, \mathrm{C}=\mathrm{CH}), 3.73\left(4 \mathrm{H}, \mathrm{t}, \mathrm{CH}_{2} \mathrm{OCH}_{2}\right), 3.02\left(4 \mathrm{H}, \mathrm{t}, \mathrm{CH}_{2} \mathrm{NCH}_{2}\right), 2.34\left(3 \mathrm{H}, \mathrm{s}, \mathrm{CH}_{3}\right) . \delta_{\mathrm{C}}$ (CDCl3) 155.9 (s), 146.0 (s), 130.8 (s), 128.6 (2 d), 125.2 (2d), 90.9 (d), 63.5 (2t), 43.3 (2t), 20.9 (q).

Anal. Calcd for $\mathrm{C}_{13} \mathrm{H}_{17} \mathrm{NO}_{3} \mathrm{~S}$ : C 58.40, H 6.41, N 5.24. Found: C 58.52, H 6.49, N 5.19. 
(E)-1-Phenylsulfonyl-2-(1-pyrrolidinyl)propene (9d). The thick oil was crystallized from $n$ pentane, Mp $91{ }^{\circ} \mathrm{C}(95 \%$ yield $)$. IR data $\left(\mathrm{cm}^{-1}\right): 3010(=\mathrm{C}-\mathrm{H}), 1540(\mathrm{C}=\mathrm{C}), 1480,1385,750,710$ $(\mathrm{Ph})$, 1270, 1130, $1080\left(\mathrm{SO}_{2}\right), 820(=\mathrm{C}-\mathrm{H}) . \mathrm{NMR}$ data: $\delta_{\mathrm{H}}\left(\mathrm{CDCl}_{3}\right) 7.88(2 \mathrm{H}, \mathrm{m}, \mathrm{Ar}-\mathrm{H}), 7.44(3$ $\mathrm{H}, \mathrm{m}, \mathrm{Ar}-\mathrm{H}), 4.86(1 \mathrm{H}, \mathrm{s}, \mathrm{C}=\mathrm{CH}), 3.33\left(2 \mathrm{H}\right.$, broad signal, $\left.\mathrm{CH}_{2} \mathrm{~N}\right), 3.10(2 \mathrm{H}$, broad signal, $\mathrm{CH}_{2} \mathrm{~N}$ ), $2.18\left(3 \mathrm{H}, \mathrm{s}, \mathrm{CH}_{3}\right), 1.90\left(4 \mathrm{H}, \mathrm{m}, \mathrm{NCH}_{2} \mathrm{CH}_{2} \mathrm{CH}_{2}\right) . \delta_{\mathrm{C}}\left(\mathrm{CDCl}_{3}\right) 156.2(\mathrm{~s}), 146.3(\mathrm{~s}), 131.1$ (d), 128.6 (2d), 125.9 (2d), 91.6 (d), 48.1 (t), 24.9 (t), 16.3 (q). Anal. Calcd for $\mathrm{C}_{13} \mathrm{H}_{17} \mathrm{NO}_{2} \mathrm{~S}: \mathrm{C}$ 62.12, H 6.82, N 5.57. Found: C 62.13, H 7.01, N 5.58.

(S,E)-2-(2-Methoxycarbonyl-1-pyrrolidinyl)-1-phenylsulfonylpropene (9e). Proline methyl ester hydrochloride $(0.42 \mathrm{~g}, 2.5 \mathrm{mmol})$ was dissolved in water $(1 \mathrm{~mL})$ and $\mathrm{NaHCO}_{3}(0.21 \mathrm{~g}, 2.5$ $\mathrm{mmol})$ was added. When evolution of $\mathrm{CO}_{2}$ ceased, the ketone 7 (0.63 g, $\left.2.5 \mathrm{mmol}\right)$ in $\mathrm{CH}_{2} \mathrm{Cl}_{2}(10$ $\mathrm{mL}$ ) was added. The supernatant water was then taken off and a small amount of anh. $\mathrm{Na}_{2} \mathrm{SO}_{4}$ was added. The mixture was stirred for $12 \mathrm{~h}$, the solvent was removed and the product was recovered as a thick oil $(0.71 \mathrm{~g}, 93 \%$ yield $)$. IR data $\left(\mathrm{cm}^{-1}\right): 1740\left(\mathrm{CO}_{2} \mathrm{CH}_{3}\right), 1550(\mathrm{C}=\mathrm{C}), 1320$, 1310, 1280, $1130\left(\mathrm{SO}_{2}\right), 820(=\mathrm{C}-\mathrm{H})$. NMR data: $\delta_{\mathrm{H}}\left(\mathrm{CDCl}_{3}\right) 7.89(2 \mathrm{H}, \mathrm{d}, \mathrm{Ar}-\mathrm{H}), 7.46(3 \mathrm{H}, \mathrm{m}$, Ar-H), $4.95(1 \mathrm{H}, \mathrm{bs}, \mathrm{C}=\mathrm{CH}), 4.28\left(1 \mathrm{H}, \mathrm{dd}, \mathrm{CHCO}_{2}\right), 3.72\left(3 \mathrm{H}, \mathrm{s}, \mathrm{CO}_{2} \mathrm{CH}_{3}\right), 3.40(4 \mathrm{H}, \mathrm{m}$, $\mathrm{CH}_{2} \mathrm{NCH}_{2}$ ), 2.20 (3 H, s, $\left.\mathrm{CH}_{3}\right), 2.10,2.04$ (4 H, 2 bm, $\left.\mathrm{NCHCH}_{2} \mathrm{CH}_{2}\right) . \delta_{\mathrm{C}}\left(\mathrm{CDCl}_{3}\right) 172.4(\mathrm{~s})$, $155.8(\mathrm{~s}), 145.8(\mathrm{~s}), 131.5(\mathrm{~d}), 128.2$ (2 d), $126.0(2 \mathrm{~d}), 94.6(\mathrm{~d}), 60.6(\mathrm{~d}), 52.5(\mathrm{q}), 48.7$ (t), 30.5, $(\mathrm{t}), 23.2(\mathrm{t}), 16.1(\mathrm{q}) \cdot[\alpha]_{\mathrm{D}}^{23}=-60.3\left(\mathrm{c}=0.59, \mathrm{CHCl}_{3}\right)$.

\section{Reactions of vinylogous sulfonamides}

All the reactions were performed between the substrate $(2.5 \mathrm{mmol})$ and an equimolar amount of electrophile. The reactions with the nitroolefins were carried out in the absence of solvent. The crude reaction mixtures were subsequently hydrolysed with $2 \mathrm{~N} \mathrm{HCl}$, extracted with $\mathrm{CH}_{2} \mathrm{Cl}_{2}$ and the organic layers evaporated to dryness.

\section{Reaction with methyl iodide}

A mixture of the appropriate sulfonamide $(9 \mathbf{d}, 9 \mathbf{9 e})$ and methyl iodide in excess was heated at reflux for $24 \mathrm{~h}$. From the reaction of $\mathbf{9 d}$ the immonium salt intermediate 14 was isolated, $\mathrm{Mp}$ 174- $176^{\circ} \mathrm{C}$, after rapid washings with abs. EtOH and diethyl ether. IR data $\left(\mathrm{cm}^{-1}\right): 1640(\mathrm{C}=\mathrm{N}+)$, 1380, 715, 685, $675(\mathrm{Ph}), 1325,1300,1135\left(\mathrm{SO}_{2}\right)$. NMR data: $\delta_{\mathrm{H}}\left(\mathrm{CDCl}_{3}\right) 7.93(2 \mathrm{H}, \mathrm{m}, \mathrm{Ar}-\mathrm{H})$, $7.81(1 \mathrm{H}, \mathrm{m}, \mathrm{Ar}-\mathrm{H}), 7.69(2 \mathrm{H}, \mathrm{m}, \mathrm{Ar}-\mathrm{H}), 4.80\left(1 \mathrm{H}, \mathrm{q}, \mathrm{CHCH}_{3}\right), 4.78\left(2 \mathrm{H}, \mathrm{m}, \mathrm{CH}_{2} \mathrm{~N}\right), 3.91(2$ $\left.\mathrm{H}, \mathrm{m}, \mathrm{CH}_{2} \mathrm{~N}\right), 2.73\left(3 \mathrm{H}, \mathrm{s}, \mathrm{CH}_{3} \mathrm{C}=\mathrm{N}\right), 2.45\left(2 \mathrm{H}, \mathrm{m}, \mathrm{CH}_{2} \mathrm{CH}_{2} \mathrm{~N}\right), 2.20\left(2 \mathrm{H}, \mathrm{m}, \mathrm{CH}_{2} \mathrm{CH}_{2} \mathrm{~N}\right), 1.82$ $\left(3 \mathrm{H}, \mathrm{d}, \mathrm{CHCH}_{3}\right) . \delta_{\mathrm{C}}\left(\mathrm{CDCl}_{3}\right) 179.7$ (s), $135.8(\mathrm{~s}), 135.5$ (d), $130.0(2 \mathrm{~d}), 129.0(2 \mathrm{~d}), 66.6(\mathrm{~d}), 57.8$ $(\mathrm{t}), 57.7(\mathrm{t}), 24.5(\mathrm{t}), 24.0(\mathrm{t}), 23.4(\mathrm{q}), 14.4(\mathrm{q})$.

3-Phenylsulfonyl-2-butanone (13). M.p. 94-95 ${ }^{\circ} \mathrm{C}\left[\right.$ lit. $\left.^{14} 96-97{ }^{\circ} \mathrm{C}\right](35 \%$ yield from $9 d) . \mathrm{R}_{\mathrm{f}}=$ 0.30 (light petroleum/AcOEt 80:20). IR data $\left(\mathrm{cm}^{-1}\right): 1720(\mathrm{C}=\mathrm{O}), 1280,1120\left(\mathrm{SO}_{2}\right), 760,700$, $690(\mathrm{Ph})$. NMR data: $\delta_{\mathrm{H}}\left(\mathrm{CDCl}_{3}\right) 7.81(2 \mathrm{H}, \mathrm{m}, \mathrm{Ar}-\mathrm{H}), 7.68(1 \mathrm{H}, \mathrm{m}, \mathrm{Ar}-\mathrm{H}), 7.57(2 \mathrm{H}, \mathrm{m}, \mathrm{Ar}-\mathrm{H})$, $4.15\left(1 \mathrm{H}, \mathrm{q}, \mathrm{CHCH}_{3}\right), 2.44\left(3 \mathrm{H}, \mathrm{s}, \mathrm{CH}_{3} \mathrm{CO}\right), 1.41\left(3 \mathrm{H}, \mathrm{d}, \mathrm{CHCH}_{3}\right) . \delta_{\mathrm{C}}\left(\mathrm{CDCl}_{3}\right) \delta 200.1(\mathrm{~s})$, 136.3 (s), 134.3 (d), 129.2 (2d), 129.1 (2d), 70.8 (d), 30.8 (q), 11.8 (q).

\section{Reaction with 2-nitropropene}

The reactions with vinylogous sulfonamides 9d and 9e were carried out under different conditions, the former in $\mathrm{CHCl}_{3}$ the latter in anhydrous $\mathrm{THF}$, at $-10^{\circ} \mathrm{C}$. After acidic hydrolysis 
and the usual work-up, the regioisomers $\mathbf{1 5}$ and $\mathbf{1 6}$ were separated by flash chromatography (light petroleum/AcOEt from 95/5 to 65/35)

syn-, anti-5-Nitro-3-phenylsulfonyl-2-hexanone (15, 16). Oil. It is a 45:55 diastereomeric mixture. NMR data: $\delta_{\mathrm{H}}\left(\mathrm{CDCl}_{3}\right) 7.78(3 \mathrm{H}, \mathrm{m}, \mathrm{Ar}-\mathrm{H}), 7.72(2 \mathrm{H}, \mathrm{m}, \mathrm{Ar}-\mathrm{H}), 4.71(0.45 \mathrm{H}, \mathrm{m}$, $\left.\mathrm{CHNO}_{2}\right), 4.34\left(0.55 \mathrm{H}, \mathrm{m}, \mathrm{CHNO}_{2}\right), 4.28\left(0.45 \mathrm{H}, \mathrm{dd},{ }^{3} \mathrm{~J}=5.5 \mathrm{~Hz},{ }^{3} \mathrm{~J}=7.0 \mathrm{~Hz}, \mathrm{CHSO}_{2}\right), 2.54$ $\left(0.22 \mathrm{H}, \mathrm{ddd},{ }^{3} \mathrm{~J}=15.5 \mathrm{~Hz},{ }^{3} \mathrm{~J}=9.5 \mathrm{~Hz},{ }^{3} \mathrm{~J}=7.0 \mathrm{~Hz}, \mathrm{CHCHSO}_{2}\right), 2.48\left(1.65 \mathrm{H}, \mathrm{s}, \mathrm{CH}_{3} \mathrm{CO}\right), 2.39$ $\left(1.35 \mathrm{H}, \mathrm{s}, \mathrm{CH}_{3} \mathrm{CO}\right), 2.36\left(0.22 \mathrm{H}, \mathrm{ddd},{ }^{3} \mathrm{~J}=15.5 \mathrm{~Hz},{ }^{3} \mathrm{~J}=5.5 \mathrm{~Hz},{ }^{3} \mathrm{~J}=4.3 \mathrm{~Hz}, \mathrm{CHCHSO}_{2}\right), 2.30$ $\left(1.1 \mathrm{H}, \mathrm{m}, \mathrm{CH}_{2}\right), 1.52\left(1.35 \mathrm{H}, \mathrm{d}, \mathrm{CH}_{3}\right), 1.50$ (1.65 H, d, $\left.\mathrm{CH}_{3}\right) . \delta_{\mathrm{C}}(\mathrm{CDCl} 3) 198.3$ (s), 198.2 (s), 135.8 (s), 135.7 (s), 134.9 (d), 129.4 (d), 129.3 (d), 129.2 (d), 80.6 (d), 80.0 (d), 72.5 (d), 71.6 (d), 32.8 (t), 31.9 (t), 31.5 (q), 31.5 (q), 19.3 (q), 19.2 (q).

5-Nitro-1-phenylsulfonyl-2-hexanone (17). Oil. NMR data: $\delta_{\mathrm{H}}\left(\mathrm{CDCl}_{3}\right) 7.88(2 \mathrm{H}, \mathrm{d}, \mathrm{Ar}-\mathrm{H})$, $7.69(1 \mathrm{H}, \mathrm{m}, \mathrm{Ar}-\mathrm{H}), 7.60(2 \mathrm{H}, \mathrm{m}, \mathrm{Ar}-\mathrm{H}), 4.56\left(1 \mathrm{H}, \mathrm{ddq},{ }^{3} \mathrm{~J}=6.7 \mathrm{~Hz},{ }^{3} \mathrm{~J}=4.6 \mathrm{~Hz},{ }^{3} \mathrm{~J}=9.1 \mathrm{~Hz}\right.$, $\left.\mathrm{CHNO}_{2}\right), 4.18\left(2 \mathrm{H}, \mathrm{s}, \mathrm{CH}_{2} \mathrm{SO}_{2}\right), 2.80\left(2 \mathrm{H}, \mathrm{t}, \mathrm{CH}_{2} \mathrm{CO}\right), 2.16\left(2 \mathrm{H}, \mathrm{m}, \mathrm{CHCHNO}_{2}\right), 2.11(1 \mathrm{H}, \mathrm{m}$, $\left.\mathrm{CHCHNO}_{2}\right), 1.53\left(3 \mathrm{H}, \mathrm{d}, \mathrm{J}\right.$ 6.7, $\left.\mathrm{CH}_{3}\right) . \delta_{\mathrm{C}}\left(\mathrm{CDCl}_{3}\right) 196.4$ (s), 134.4 (d), 129.4 (d), 128.1 (d), 82.0 (d), $66.8(\mathrm{t}), 40.1(\mathrm{t}), 28.1(\mathrm{t}), 19.2(\mathrm{q})$.

\section{Reactions with $\beta$-nitrostyrene}

(E)-5-Nitro-4-phenyl-1-phenylsulfonyl-2-(1-pyrrolidinyl)-1-pentene (18d). Mp 139-142 ${ }^{\circ} \mathrm{C}$. IR data $\left(\mathrm{cm}^{-1}\right): 1550\left(\mathrm{~N}-\mathrm{C}=\mathrm{C}, \mathrm{NO}_{2}\right), 1290,1140\left(\mathrm{SO}_{2}\right), 1600,1500,750,720,690(\mathrm{Ph})$. NMR data: $\delta_{\mathrm{H}}\left(\mathrm{CDCl}_{3}\right) 7.90(2 \mathrm{H}, \mathrm{m}, \mathrm{Ar}-\mathrm{H}), 7.52(3 \mathrm{H}, \mathrm{m}, \mathrm{Ar}-\mathrm{H}), 7.34(5 \mathrm{H}, \mathrm{m}, \mathrm{Ar}-\mathrm{H}), 4.92(1 \mathrm{H}, \mathrm{s}$, $\mathrm{C}=\mathrm{CH}), 4.90\left(2 \mathrm{H}, \mathrm{m}, \mathrm{CH}_{2} \mathrm{NO}_{2}\right), 3.80(2 \mathrm{H}, \mathrm{m}, \mathrm{C}=\mathrm{CCH}, \mathrm{CHPh}), 3.20\left(4 \mathrm{H}, \mathrm{b}\right.$ signal, $\left.\mathrm{CH}_{2} \mathrm{NCH}_{2}\right)$, $2.46(1 \mathrm{H}, \mathrm{m}, \mathrm{C}=\mathrm{CCH}), 1.90\left(4 \mathrm{H}, \mathrm{b}\right.$ signal $\left.\left(\mathrm{CH}_{2}\right)_{2}\right) . \delta_{\mathrm{C}}\left(\mathrm{CDCl}_{3}\right) 154.5(\mathrm{~s}), 145.4(\mathrm{~s}), 138.5(\mathrm{~s})$, 130.8 (d), 128.2 (2 d), 128.1 (2 d), 127.2 (d), 126.5 (2 d), 124.9 (2 d), 92.7 (d), 77.9 (t), 48.3 (very broad signal, 2 t), $41.6(\mathrm{~d}), 33.0(\mathrm{t}), 24.5$ (very broad signal, $2 \mathrm{t}$ ). Anal. Calcd. for $\mathrm{C}_{21} \mathrm{H}_{24} \mathrm{~N}_{2} \mathrm{O}_{4} \mathrm{~S}$ : C 62.98; H 6.04; N 6.99. Found: C 62.93, H 6.15, N 6.87.

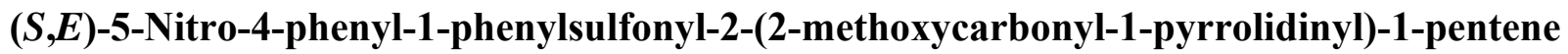

(18e). Treatment of the crude reaction mixture with absolute EtOH allowed the isolation of the nitroalkylated enamine 18e as a white solid. An NMR analysis of the mother liquors excluded the presence of any other diastereoisomer. M.p: $135-137^{\circ} \mathrm{C}$. IR data $\left(\mathrm{cm}^{-1}\right): 1745$ (COO), 1540 $\left(\mathrm{C}=\mathrm{C}, \mathrm{NO}_{2}\right), 1370\left(\mathrm{NO}_{2}\right), 1280,1270,1120\left(\mathrm{SO}_{2}\right), 1600,1490,750,720(\mathrm{Ph}) . \mathrm{NMR}$ data: $\delta_{\mathrm{H}}$ $\left(\mathrm{CDCl}_{3}\right) 7.82(2 \mathrm{H}, \mathrm{m}, \mathrm{Ar}-\mathrm{H}), 7.50(3 \mathrm{H}, \mathrm{m}, \mathrm{Ar}-\mathrm{H}), 7.30$ (5 H, m, Ar-H), 4.92 (3 H, broad signal, $\left.\mathrm{C}=\mathrm{CH}, \mathrm{CH}_{2} \mathrm{NO}_{2}\right), 4.10\left(1 \mathrm{H}, \mathrm{bm}, \mathrm{NCHCO}_{2} \mathrm{CH}_{3}\right), 3.9-3.2\left(7 \mathrm{H}\right.$, broad multiplets, $\mathrm{CH}_{2} \mathrm{~N}$, $\left.\mathrm{C}=\mathrm{CCH}, \mathrm{CHPh}, \mathrm{CH}_{3}\right), 2.63(1 \mathrm{H}, \mathrm{bm}, \mathrm{C}=\mathrm{CCH}), 2.10,1.95\left(4 \mathrm{H}, \mathrm{b}\right.$ multiplets $\left.\left(\mathrm{CH}_{2}\right)_{2}\right) . \delta_{\mathrm{C}}$ $\left(\mathrm{CDCl}_{3}\right) 172.3$ (s), 154.8 (bs), 154.5 (s), 139.3 (s), 132.0 (d), 129.2 (2d), 129.0 (2d), 128.1 (2d), $127.4(2 \mathrm{~d}), 125.9(\mathrm{~d}), 96.5(\mathrm{bd}), 78.6(\mathrm{t}), 61.2(\mathrm{~d}), 52.6(\mathrm{q}), 48.9(\mathrm{t}), 42.3(\mathrm{~d}), 33.5(\mathrm{t}), 30.4(\mathrm{t})$, 23.2 (t). Anal. Calcd. for $\mathrm{C}_{23} \mathrm{H}_{26} \mathrm{~N}_{2} \mathrm{O}_{6} \mathrm{~S}$ : C 60.25; H 5.72; N 6.11. Found: C 59.85, H 5.93, $\mathrm{N}$ 5.97. $[\alpha]_{\mathrm{D}}^{25}=-42.2\left(\mathrm{c} 0.30, \mathrm{CHCl}_{3}\right)$.

5-Nitro-4-phenyl-1-phenylsulfonyl-2-pentanone (19). $\mathrm{Mp} 167-8^{\circ} \mathrm{C} . \mathrm{NMR}$ data: $\delta_{\mathrm{H}}\left(\mathrm{CDCl}_{3}\right)$ 7.65 (2 H, m, Ar-H), 7.48 (2 H, m, Ar-H), 7.33 (4 H, m, Ar-H), 7.25 (2 H, m, Ar-H), 4.65, 4.58 $\left(2 \mathrm{H}, 2\right.$ quartets, $\mathrm{AB}$ part of an $\mathrm{ABX}$ system, $\left.{ }^{2} \mathrm{~J}=13.2 \mathrm{~Hz}, \mathrm{CH}_{2} \mathrm{NO}_{2}\right), 4.13,4.02(2 \mathrm{H}, \mathrm{AB}$ system, $\left.{ }^{2} \mathrm{~J}=13.2 \mathrm{~Hz}, \mathrm{CH}_{2} \mathrm{SO}_{2}\right), 4.00(1 \mathrm{H}$, quintet, $\mathrm{J}=7.6 \mathrm{~Hz}, \mathrm{CHPh}), 3.37\left(1 \mathrm{H}, \mathrm{dd},{ }^{2} \mathrm{~J}=18.6\right.$ 
$\left.\mathrm{Hz},{ }^{3} \mathrm{~J}=7.6 \mathrm{~Hz}, \mathrm{CHCO}\right), 3.16\left(1 \mathrm{H}, \mathrm{dd},{ }^{2} \mathrm{~J}=18.6 \mathrm{~Hz},{ }^{3} \mathrm{~J}=6.1 \mathrm{~Hz}, \mathrm{CHCO}\right) . \delta_{\mathrm{C}}(\mathrm{CDCl} 3) 199.6(\mathrm{~s})$, 138.3 (s), 134.5 (s), 129.5 (2 d), 129.4 (2 d), 128.2 (2 d), 128.1 (d), 127.7 (3 d), 79.0 (t), 67.1 (t), 46.9 (t), 38.7 (d). Anal. Calcd. for $\mathrm{C}_{17} \mathrm{H}_{17} \mathrm{NO}_{5} \mathrm{~S}$ : C 58.78; H 4.93; N 4.03. Found: C 59.05, $\mathrm{H}$ 5.15, N 3.97. $[\alpha]_{\mathrm{D}}{ }^{26}=-12.6\left(\mathrm{c} 0.31, \mathrm{CHCl}_{3}\right)$. The same ketone isolated from the reaction of enmine 9b with $\beta$-nitrostyrene had $[\alpha]_{\mathrm{D}}{ }^{26}=+6.1\left(\mathrm{c} 0.18, \mathrm{CHCl}_{3}\right)$.

\section{Reaction with 2-nitro-1-phenylpropene}

(E)-5-Nitro-4-phenyl-1-phenylsulfonyl-2-(1-pyrrolidinyl)-1-hexene (20d, 21d). NMR data: $\delta_{\mathrm{H}}$ $\left(\mathrm{CDCl}_{3}\right) 7.93$ (2 H, m, Ar-H), 7.47 (4 H, m, Ar-H), 7.30 (1 H, m, Ar-H), 7.15 (2 H, m, Ar-H), $7.08(1 \mathrm{H}, \mathrm{m}, \mathrm{Ar}-\mathrm{H}), 5.19\left(1 \mathrm{H}, \mathrm{m}, \mathrm{CHNO}_{2}\right), 4.76(0.5 \mathrm{H}, \mathrm{s}, \mathrm{C}=\mathrm{CH}), 4.74(0.5 \mathrm{H}, \mathrm{s}, \mathrm{C}=\mathrm{CH}), 3.73$ (0.5 H, q, CHPh), $3.64(1 \mathrm{H}, \mathrm{m}, \mathrm{CHPh}, \mathrm{CHC}=\mathrm{C}), 3.35(2.5 \mathrm{H}, \mathrm{bm}, \mathrm{CHN}, \mathrm{CHC}=\mathrm{C}), 2.55(0.5 \mathrm{H}$, $\mathrm{m}, \mathrm{CHC}=\mathrm{C}), 1.75,1.71\left(3.5 \mathrm{H}, \mathrm{m}+\mathrm{d}, \mathrm{CH}_{2} \mathrm{CH}_{2} \mathrm{CH}_{2} \mathrm{~N}, \mathrm{CH}_{3}\right), 1.55\left(2 \mathrm{H}, \mathrm{m}, \mathrm{CH}_{2} \mathrm{CH}_{2} \mathrm{CH}_{2} \mathrm{~N}\right), 1.31$ $\left(1.5 \mathrm{H}, \mathrm{d}, \mathrm{CH}_{3}\right) . \delta_{\mathrm{C}}\left(\mathrm{CDCl}_{3}\right) 156.7$ (s), 155.2 (s), 146.2 (s), 137.8 (s), 137.6 (s), 131.6 (d), 131.5 (d), 129.0 (2 d), 128.9 (2 d), 128.8 (2 d) 128.7 (2 d), 128.5 (2 d), 128.2 (2 d), 128.1 (2 d), 128.0 (2d), 126.0 (d), 125.9 (d), 94.1 (d), 92.3 (d), 86.7 (d), 86.3 (d), 49.3 (d), 48.5 (2 t), 45.2 (d), 32.8 (t), 24.9 (2 t), 18.3 (q), 14.1 (q).

(S,E)-5-Nitro-4-phenyl-1-phenylsulfonyl-2-(2-methoxycarbonyl-1-pyrrolidinyl)-1-hexene (20e, 21e). IR data (cm $\left.{ }^{-1}\right): 1720(\mathrm{CO}), 1550,1370\left(\mathrm{NO}_{2}\right), 1310,1305,1150\left(\mathrm{SO}_{2}\right), 1600,1580$, 760, 740, 700, $690(\mathrm{Ph})$. NMR data: $\delta_{\mathrm{H}}\left(\mathrm{CDCl}_{3}\right) 7.90(2 \mathrm{H}, \mathrm{m}, \mathrm{Ar}-\mathrm{H}), 7.65(2 \mathrm{H}, \mathrm{m}, \mathrm{Ar}-\mathrm{H}), 7.50$ (3 H, m, Ar-H), 7.20 (2 H, m, Ar-H), 7.10 (1 H, m, Ar-H), 5.15 (1 H, m, $\left.\mathrm{CHNO}_{2}\right), 4.70,4.68$ (1 $\mathrm{H}, 2 \mathrm{~s}, \mathrm{C}=\mathrm{CH}), 4.23\left(1 \mathrm{H}, \mathrm{b}\right.$ signal, $\left.\mathrm{CHCO}_{2} \mathrm{CH}_{3}\right), 3.69,3.63\left(3 \mathrm{H}, 2 \mathrm{~s}, \mathrm{COOCH}_{3}\right), 3.503 .20(5 \mathrm{H}$, m, $\left.\mathrm{CHPh}, \mathrm{CH}_{2} \mathrm{~N}, \mathrm{CH}_{2} \mathrm{C}=\mathrm{C}\right), 2.2-1.7\left(4 \mathrm{H}, \mathrm{m}, \mathrm{CH}_{2} \mathrm{CH}_{2} \mathrm{CH}_{2} \mathrm{~N}\right), 1.69\left(1.5 \mathrm{H}, \mathrm{d}, \mathrm{CH}_{3}\right), 1.32$ (1.5 $\left.\mathrm{H}, \mathrm{d}, \mathrm{CH}_{3}\right) . \delta_{\mathrm{C}}\left(\mathrm{CDCl}_{3}\right) 171.8$ (s), 171.7 (s), 155.9 (s), 154.7 (s), 145.2 (s), 145.1 (s), 137.3 (s), 137.2 (s), 131.3 (d), 131.2 (d), 128.4 (2d), 128.3 (2d), 128.1 (2d), 127.7 (d), 127.6 (d), 127.4 (2d), 127.3 (2d), 125.3 (2d), 125.2 (2d), 95.7 (bd), $93.6(\mathrm{bd}), 84.0$ (d), $83.6(\mathrm{~d}), 60.9$ (d), 60.6 (d), $51.7(\mathrm{q}), 51.8(\mathrm{q}), 48.5(\mathrm{t}), 48.3(\mathrm{t}), 47.3(\mathrm{~d}), 31.4(\mathrm{t}), 29.5(\mathrm{t}), 29.4(\mathrm{t}), 22.7(\mathrm{t}), 17.7(\mathrm{q}), 17.6(\mathrm{q})$. syn-5-Nitro-4-phenyl-1-phenylsulfonyl-2-hexanone (22). $\mathrm{Mp} 121-122^{\circ} \mathrm{C}, \mathrm{R}_{\mathrm{f}}=0.70$ (light petroleum/AcOEt 60:40). IR data $\left(\mathrm{cm}^{-1}\right): 1720(\mathrm{CO}), 1550,1370\left(\mathrm{NO}_{2}\right), 1310,1305,1150\left(\mathrm{SO}_{2}\right)$, 1600, 1580, 760, 740, 700, $690(\mathrm{Ph})$. NMR data: $\delta_{\mathrm{H}}\left(\mathrm{CDCl}_{3}\right) 7.63(3 \mathrm{H}, \mathrm{m}, \mathrm{Ar}-\mathrm{H}), 7.47(2 \mathrm{H}, \mathrm{m}$, Ar-H), 7.31 (3 H, m, Ar-H), 7.18 (2 H, m, Ar-H), 4.84 (1 H, quintet, $\left.{ }^{3} \mathrm{~J}=6.8 \mathrm{~Hz}, \mathrm{CHNO}_{2}\right), 4.14$, $\left(1 \mathrm{H}, \mathrm{d},{ }^{2} \mathrm{~J}=12.2 \mathrm{~Hz}, \mathrm{CHSO}_{2}\right), 3.98\left(1 \mathrm{H}, \mathrm{d},{ }^{2} \mathrm{~J}=12.2 \mathrm{~Hz}, \mathrm{CHSO}_{2}\right), 3.72(1 \mathrm{H}, \mathrm{m}, \mathrm{CHPh}), 3.40$ $\left(1 \mathrm{H}, \mathrm{dd},{ }^{2} \mathrm{~J}=18.5 \mathrm{~Hz},{ }^{3} \mathrm{~J}=8.5 \mathrm{~Hz}, \mathrm{CHCO}\right), 3.21\left(1 \mathrm{H},{ }^{2} \mathrm{~J}=18.5 \mathrm{~Hz},{ }^{3} \mathrm{~J}=5.4 \mathrm{~Hz}, \mathrm{CHCO}\right), 1.52(3$ $\left.\mathrm{H}, \mathrm{d},{ }^{3} \mathrm{~J}=6.8 \mathrm{~Hz}, \mathrm{CH}_{3}\right) . \delta_{\mathrm{C}}\left(\mathrm{CDCl}_{3}\right) 195.3$ (s), 138.0 (s), 137.5 (s), 134.3 (d), 129.3 (2d), 128.8 (2d), $128.3(2 \mathrm{~d}), 128.2$ (2d) 128.1 (d), 86.0 (d), 67.3 (t), 45.5 (t), 44.3 (d), 16.7 (q). Anal. Calcd. for $\mathrm{C}_{18} \mathrm{H}_{19} \mathrm{NO}_{5} \mathrm{~S}$ : C 59.82; H 5.30; N 3.88. Found C 59.81, H 5.23, N 3.76. $[\alpha]_{\mathrm{D}}{ }^{25}=-12.0$ (c $\left.0.25, \mathrm{CHCl}_{3}\right)$.

anti-5-Nitro-4-phenyl-1-phenylsulfonyl-2-hexanone (23). $\mathrm{Mp} 120-122^{\circ} \mathrm{C}, \mathrm{R}_{\mathrm{f}}=0.82$ (light petroleum/AcOEt 60:40). IR data $\left(\mathrm{cm}^{-1}\right): 1720(\mathrm{CO}), 1550,1370\left(\mathrm{NO}_{2}\right), 1310,1305,1150\left(\mathrm{SO}_{2}\right)$, 1600, 1580, 760, 740, 700, $690(\mathrm{Ph}) . \mathrm{NMR}$ data: $\delta_{\mathrm{H}}\left(\mathrm{CDCl}_{3}\right) 7.59(1 \mathrm{H}, \mathrm{m}, \mathrm{Ar}-\mathrm{H}), 7.37(7 \mathrm{H}, \mathrm{m}$, Ar-H), $7.23(2 \mathrm{H}, \mathrm{m}, \mathrm{Ar}-\mathrm{H}), 4.78\left(1 \mathrm{H}, \mathrm{dq},{ }^{3} \mathrm{~J}=9.8 \mathrm{~Hz},{ }^{3} \mathrm{~J}=6.7 \mathrm{~Hz}, \mathrm{CHNO}_{2}\right), 4.10\left(1 \mathrm{H}, \mathrm{d},{ }^{2} \mathrm{~J}=\right.$ $\left.13.0 \mathrm{~Hz}, \mathrm{CHSO}_{2}\right), 3.87\left(1 \mathrm{H}, \mathrm{d},{ }^{2} \mathrm{~J}=13.0 \mathrm{~Hz}, \mathrm{CHSO}_{2}\right), 3.67\left(1 \mathrm{H}, \mathrm{dt},{ }^{3} \mathrm{~J}=9.8 \mathrm{~Hz},{ }^{3} \mathrm{~J}=3.4 \mathrm{~Hz},{ }^{3} \mathrm{~J}\right.$ 
$=9.8 \mathrm{~Hz}, \mathrm{CHPh}), 3.54\left(1 \mathrm{H}, \mathrm{dd},{ }^{2} \mathrm{~J}=18.2 \mathrm{~Hz},{ }^{3} \mathrm{~J}=9.8 \mathrm{~Hz}, \mathrm{CHCHPh}\right), 2.90\left(1 \mathrm{H}, \mathrm{dd},{ }^{2} \mathrm{~J}=18.2\right.$ $\left.\mathrm{Hz},{ }^{3} \mathrm{~J}=3.4 \mathrm{~Hz}, \mathrm{CHCHPh}\right), 1.31\left(3 \mathrm{H}, \mathrm{d},{ }^{3} \mathrm{~J}=6.7 \mathrm{~Hz}, \mathrm{CH}_{3}\right) . \delta_{\mathrm{C}}\left(\mathrm{CDCl}_{3}\right) 194.7$ (s), $137.6(\mathrm{~s})$, 137.5 (s), 134.2 (d), 129.2 (2d), 129.1 (2d), 128.6 (2d), 128.2 (2d), 128.0 (d), 86.7 (d), 67.2 (t), 46.9 (t), 44.9 (d), 17.8 (q). Anal. Calcd. for $\mathrm{C}_{18} \mathrm{H}_{19} \mathrm{NO}_{5} \mathrm{~S}$ : C 59.82; H 5.30; N 3.88. Found: C 59.78, H 5.25, N 3.87. $[\alpha]_{\mathrm{D}}^{25}=-32.0\left(\mathrm{c} 0.25, \mathrm{CHCl}_{3}\right)$.

\section{Reaction with $\alpha$-nitrostilbene}

syn-, anti-5-Nitro-4,5-diphenyl-1-phenylsulfonyl-2-pentanone (24, 25). Mp $151^{\circ} \mathrm{C}(25 \%$ yield from 9e). $\mathrm{R}_{\mathrm{f}}=0.38$ (light petroleum/AcOEt 60:40). IR data $\left(\mathrm{cm}^{-1}\right)$ : 1720 (CO), 1550, 1370 $\left(\mathrm{NO}_{2}\right), 1315,1310,1150\left(\mathrm{SO}_{2}\right), 1580,1500,740,720,700,690(\mathrm{Ph})$. NMR data: $\delta_{\mathrm{H}} 7.57(3 \mathrm{H}$, m, Ar-H), 7.47 (3H, m, Ar-H), $7.4-7.3(7 \mathrm{H}, \mathrm{m}, \mathrm{Ar}-\mathrm{H}), 5.77\left(1 \mathrm{H}, \mathrm{d}, \mathrm{J}=11.9 \mathrm{~Hz}, \mathrm{CHNO}_{2}\right), 4.30$ $\left(1 \mathrm{H}, \mathrm{dt},{ }^{3} \mathrm{~J}=2.1 \mathrm{~Hz},{ }^{3} \mathrm{~J}=11.0 \mathrm{~Hz},{ }^{3} \mathrm{~J}=11.0 \mathrm{~Hz}, \mathrm{CHPh}\right), 3.87\left(1 \mathrm{H}, \mathrm{d},{ }^{2} \mathrm{~J}=12.1 \mathrm{~Hz}, \mathrm{CHSO}_{2}\right)$, $3.70\left(1 \mathrm{H}, \mathrm{d},{ }^{2} \mathrm{~J}=12.1 \mathrm{~Hz}, \mathrm{CHSO}_{2}\right), 3.32\left(1 \mathrm{H}, \mathrm{dd},{ }^{2} \mathrm{~J}=18.0 \mathrm{~Hz},{ }^{3} \mathrm{~J}=10.4 \mathrm{~Hz}, \mathrm{CHCO}\right), 2.57(1 \mathrm{H}$, $\left.\mathrm{dd},{ }^{2} \mathrm{~J}=18.2 \mathrm{~Hz},{ }^{3} \mathrm{~J}=3.0 \mathrm{~Hz}, \mathrm{CHCO}\right) . \delta_{\mathrm{C}}\left(\mathrm{CDCl}_{3}\right) 194.8$ (s), 149.2 (s), 138.0 (s), 134.3 (d), 132.5 (s), 130.7 (d), 129.6 (2d), 129.2 (2d), 129.0 (2d), 128.5 (2d), 128.4 (2d), 128.1 (2d), 128.0 (d), 95.2 (d), 67.2 (t), 46.1 (t), 44.4 (d). Anal. Calcd. for $\mathrm{C}_{23} \mathrm{H}_{21} \mathrm{NO}_{5} \mathrm{~S}: \mathrm{C}$ 65.23; $\mathrm{H}$ 5.00; N 3.31 . Found: C 65.01, H 5.27, N 3.17. $[\alpha]_{\mathrm{D}}^{25}=+7.0\left(\mathrm{c} 0.33, \mathrm{CHCl}_{3}\right)$.

On standing in $\mathrm{CDCl}_{3}$, compound 24 isomerized into a 80:20 mixture of $\mathbf{2 4}$ and $\mathbf{2 5}$. The ${ }^{1} \mathrm{H}$ NMR signals of this latter compound which could be identified are given. $\delta_{\mathrm{H}} 5.65(1 \mathrm{H}, \mathrm{d}, \mathrm{J}=$ $\left.11.3 \mathrm{~Hz}, \mathrm{CHNO}_{2}\right), 4.04\left(1 \mathrm{H},{ }^{2} \mathrm{~J}=12.8 \mathrm{~Hz}, \mathrm{CHSO}_{2}\right), 3.83\left(1 \mathrm{H}, \mathrm{d},{ }^{2} \mathrm{~J}=12.8 \mathrm{~Hz}, \mathrm{CHSO}_{2}\right), 3.62(1$ $\left.\mathrm{H}, \mathrm{dd},{ }^{2} \mathrm{~J}=18.2 \mathrm{~Hz},{ }^{3} \mathrm{~J}=10.4 \mathrm{~Hz}, \mathrm{CHCO}\right), 2.86\left(1 \mathrm{H}, \mathrm{dd},{ }^{2} \mathrm{~J}=18.2 \mathrm{~Hz},{ }^{3} \mathrm{~J}=2.1 \mathrm{~Hz}, \mathrm{CHCO}\right)$.

\section{Acknowledgments}

Financial support by the M.U.R.S.T., C.N.R. (Rome) and the University of Trieste are gratefully acknowledged.

\section{References}

1. (a) Červinka, O. "Preparation of Enamines" In The Chemistry of Functional groups, The Chemistry of Enamines; Rappoport Z., Ed.; J. Wiley \& Sons: Chichester, 1994; Part 1. (b) Cook A. G. Enamines. Synthesis, Structure and Reactions; Marcel Dekker: N. Y., 1st Edn. 1969, 2nd ed. 1988. (c) Stork, G.; Brizzolara, A.; Landesman, H.; Szmuszkovicz, J.; Terrel, R. J. Am. Chem. Soc. 1963, 85, 207.

2. Hickmott, P. W. "Electrophilic and Nucleophilic Reactions of Enamines" In The Chemistry of Functional groups, The Chemistry of Enamines, Rappoport Z. Ed., J. Wiley \& Sons, Chichester, 1994; Part 1.

3. Hickmott, P. W. "Reaction of Dienamines" In The Chemistry of Functional groups, The Chemistry of Enamines, Rappoport Z., Ed.; J. Wiley \& Sons: Chichester, 1994, Part 2. 
4. Kuckländer, U. "Enaminones as Synthones" In The Chemistry of Functional groups, The Chemistry of Enamines, Rappoport Z., Ed.; J. Wiley \& Sons: Chichester, 1994, Part 1.

5. Taylor, E. C.; McKillop, A. "The Chemistry of Enaminonitriles and o-Aminonitriles" In Advances in Organic Chemistry; Wiley Interscience, 1970, Vol. 7.

6. Yamamoto, T.; Muraoke, M. Org. Prep. Proc. Int. 1984, 16, 130.

7. Rajappa, S. Tetrahedron 1999, 55, 7065; ibid. 1981, 37, 1453.

8. (a) Hanquet, G.; Colobert, F.; Lanners, S.; Solladié, G. ARKIVOC 2003, 328. (b) Ogura, K.; Tomori, H.; Fujita, M. Chem. Lett. 1991, 1407. (c) Hua, D. H.; Bharathi, S. N.; Robinson, P. D.; Tsusimoto, A. J. Org. Chem. 1990, 55, 2128. (d) Kawęcki, R.; Kozerski, L. Tetrahedron 1986, 42, 1469

9. (a) Neumann, R.; Herz, H.-G.; Maas, G. Z. Naturforsch. 2002, 57b, 427. (b) Back, Th. G.; Collins, S.; Law, K. W. Can. J. Chem. 1985, 63, 2313. (c) Houwben-Claassen, A. A. M.; McFarland, J. W.; Lammerink, B. H. M.; Thijs, L.; Zwanenburg, B. Synthesis 1983, 628. (d) Mikhailova, V. N.; Bulat, A. D.; Yurevich, V. P. Z. Ob. Khim. 1978, 48, 217; Chem. Abstr. 1978, 88, 169708. (e) Guruswamy, N.; Dharmaraj, C. R.; Ramalingam, K. Indian J. Chem. 1973, 11, 882. (f) C. J. M. Stirling, J. Chem. Soc. 1964, 5863.

10. (a) Fatutta, S.; Pitacco, G.; Valentin, E. J. Chem. Soc., Perkin Trans. I 1983, 2735. (b) Fatutta, S.; Pitacco, G.; Russo, C.; Valentin, E. J. Chem. Soc., Perkin Trans. I 1982, 2045.

11. Beck, G.; Günther, D. Chem. Ber. 1973, 106, 2758.

12. Looker, J. J. J. Org. Chem. 1966, 31, 714.

13. White, W. A.; Weingarten, H. J. Org. Chem. 1967, 32, 213.

14. Padwa, A.; Carter, S. P.; Chiacchio, U.; Kline, D. N.; Perumattam, J. J. Chem. Soc., Perkin Trans. 1 1988, 2639.

15. Jackman, L. M.; Sterhell, S. Application of Nuclear Magnetic Resonance Spectroscopy in Organic Chemistry; Pergamon Press: Oxford, 1969.

16. (a) Seebach, D.; Golinski, J. Helv. Chim. Acta 1981, 64, 1413. (b) Seebach, D.; Prelog, V. Angew. Chem. Int. Ed. Engl. 1982, 21, 654.

17. Knochel, P.; Seebach, D. Synthesis 1982, 1017.

18. Boberg, F.; Schultze, G. R. Chem. Ber. 1957, 90, 1215.

19. Robertson, D. N. J. Org. Chem. 1960, 25, 47. 